Sonia Dzierzyńska-Breś1 ${ }^{\text {(iD }) ~ h t t p: / o r c i d . ~ o r g / 0000-0002-7722-4753 ~}$

Adam Mickiewicz University in Poznań

Sylwester Matkowski ${ }^{2}$

Ośrodek Kuratorski „Klub pod Serduszkiem” w Poznaniu

\title{
THE CONCEPT OF WORKING WITH JUVENILES IN LOCAL COMMUNITY: ACTIVITIES AND INTERACTIONS BASED ON EVIDENCE-BASED PRACTICE IN ATTENDANCE CENTRES ${ }^{3}$
}

Summary: This article is based on the experiences of attendance centres in Poland. These centres, provide services to at-risk and delinquent youth in local community centres largely staffed by probation officers and volunteers who are well-versed in evidence-based concepts and practices. The primary concept that underpins these centres is to focus on socializing risk youth and juvenile delinquents in communities in which they live. The presumption is that factors related to dysfunctional social environments foster social maladjustment, which in turn, support risk factors that lead to juvenile delinquency. The services and experiences of at-risk youth and adjudicated delinquents in community-based centres appear, at least initially, to decrease individual juvenile delinquency. As well, the programs and services provided establish and support protective factors that mitigate dysfunctional social environmental factors, thereby serving an important delinquency function.

Keywords: evidence-based, attendance centre, delinquency, at-risk youth, community-based corrections

1 Dr Sonia Dzierzyńska-Breś, assistant professor, Adam Mickiewicz University in Poznań, Faculty of Educational Studies, ul. Szamarzewskiego 89, 60-568 Poznań; e-mail: sonia.d@amu.edu.pl

2 Sylwester Matkowski, bachelor, educator, social probation officer, Ośrodek Kuratorski „Klub pod Serduszkiem”, ul. Zeylanda 9/1, 60-808 Poznań; e-mail: syl.matkowski@gmail.com

3 Attendence center is institution specifically for Poland probation system. We can also translate it as a community-based educational and counselling centres. Attendance centres may be better understood outside of Poland as a structure that is somewhat similar to Day Reporting centres that purportedly offer "one stop shopping" with regard to services needed by at-risk youth and juvenile delinquents. 
In recent years, statistics show a systematic increase in juvenile delinquency in Europe and in the world ${ }^{4}$. This is a troubling phenomenon that once again brings to the fore two interdisciplinary debates: a) the effectiveness of individual versus environmental factors and their relationship to social rehabilitation; and b) whether or not to punish, isolate, exclude, and condemn at-risk youth and juvenile delinquents in order to manage risk in the short-term and change behaviour in the long-term. Both debates have informed policy and program development at one time or another, and they are particularly important as they relate to at-risk youth and juvenile delinquents. In short, society, through its elected representatives, needs to decide once and for all whether public safety is enhanced via deterrence-based policies and programs or through education and services designed to support prosocial behaviours that involve at-risk youth, their families, and their local communities ${ }^{5}$.

While there is empirical evidence ${ }^{6}$ to support that providing social rehabilitation services that focus on the individual and social environment, facilitates the management of short-term risk and long-term behavioural change it is critical to note the potential long-term benefits to at-risk youth and juvenile delinquents. Such interventions have the potential to re-shape an otherwise dismal future by interruption of pathways to criminal careers and supporting the fulfilment of prosocial roles through adulthood.

An essential element for assuring that services are provided that achieve the goals of short-term risk management and long-term behavioural reform is implement programs and services that fall under the umbrella of the phrase evidence-based practises ${ }^{7}$.

This article presents one example of a community-based program that provides services that sit, theoretically and practically, at the juncture of individual and environmental factors. In Poland, such programs are referred to as attendance centres. In this article, we present how one attendance centre in Poland has been highly effective and has contributed not only to the decrease in crime, but also performs broader prevention functions by involving the entire local community in their interactions ${ }^{8}$.

${ }^{4}$ Statystyki Biura Prewencji Komendy Głównej Policji, oraz Europejskie statystyki przestępczości, https://wp.unil.ch/europeansourcebook/ (access: 3.12.2019).

5 Efektywność resocjalizacji nieletnich $w$ warunkach wolnościowych, eds. Zdzisław Bartkowicz, Anna Wojnarska, Andrzej Węgliński (Lublin: Wydawnictwo UMCS, 2013).

6 Andy Ross, Kathryn Duckworth, David J. Smith, Gill Wyness, Ingrid Schoon, Prevention and Reduction: A Review of Strategies for Intervening Early to Prevent or Reduce Youth Crime and Anti-social Behaviour, Department for Education [DFE]), 2011, https://www.ifs.org.uk/publications/5594 (access: 15.02.2020).

7 Maciej Muskała, Odstąpienie od przestępczości w teorii i praktyce resocjalizacyjnej (Poznań: Wydawnictwo Naukowe UAM, 2016), 59-89.

8 Efektywność resocjalizacji... 
The idea of incorporating social rehabilitation programs and services in local community centres is not a new one. Research on childrens socialization processes in Poland dates back to the 1950s. Prof. Stanisław Kowalski, in his work entitled Child Offense and the Social Structure of a Family, describes the impact of dysfunctional socialization and developmental processes on the social maladjustment of children and adolescents. The prevention and social rehabilitation systems conceptualized by the Prof. Kowalski focuses on the socialization function of families, neighbourhoods, and communities, and how poor social conditions are correlated with social maladjustment of youth. Prof. Kowalski unequivocally contends that things such as a defective social environment increases the propensity for delinquency, and that protective factors are enhanced when prosocial educational/socialization systems are actively functioning 9 . The community-based attendance centre that is the subject of this article, operates on the premise that social systems are potential sources of both prosocial and deviant behavior. Therefore it is essential that efforts to risk factors associated with delinquency ground programs and services conceptually in social rehabilitation and evidence-based practices.

The local community, according to this idea is treated as a mesostructure of socialization and educational processes, mediating between macrostructure (state, nation) and microstructure (family, school). Socialization and educational processes in families, neighbourhoods, and communities change over time. They are constantly influencing individuals in both their formal and informal interactions. In this regard, informal social participation in families, neighbourhoods, and communities as well as in formal institutionalized settings that perform socialization and educational functions are critical elements in the avoidance of maladjustment. Stanisław Kowalski states that: „[...] socialization in social participation appears as the basic plane of the educational society. Socialization and education in it is what the society is in its overall functioning" ${ }^{10}$. On the one hand, the local community and its dysfunctional processes contribute to generating deviant behaviours, and on the other hand all activities that integrate and mobilize social capital provide several protective factors that are of great importance for combating risk factors for delinquency and foster prosocial behaviour ${ }^{11}$. Research indicates the lack of sufficient links between local communities and the preventive and social rehabilitation system ${ }^{12}$. Frequently, socialization programs and services are provided at the individual level and focus on one particular at-risk youth or delinquent. They do not take a more holistic approach. Such an

9 Wiesław Ambrozik, "Społeczność lokalna jako płaszczyzna funkcjonowania systemu profilaktyczno-resocjalizacyjnego", Resocjalizacja Polska 1 (2010), 157-173.

10 Stanisław Kowalski, "Środowisko lokalne w wychowawczym funkcjonowaniu społeczeństwa", Rocznik Pedagogiczny 9 (1984), 134.

11 Ambrozik, Społeczność..., 157-173.

12 Ibidem, 164-166. 
approach would systemically take into account family, peers, school, and other local institutions that the at-risk youth or juvenile delinquent routinely interacts with on daily basis.

In the idea of prevention and resocialization services that focus on socialization, based on involvement of local communities of Stanisław Kowalski, is a good fit with institution of a attendance centres. Attendance centres offer a legal community-based response as provided for in the Act on Juvenile Delinquency Proceedings (art. 6 section 6) ${ }^{13}$. "Attendance centres for juveniles work" began to appear in Poland in the 1970s under the ordinance of the Ministry of Justice of July $27,1971^{14}$. They operate in the social environment in which the at-risk youth or juvenile delinquent lives and which, by definition took into account the importance of the family, neighbourhood, and local community mitigate the process of individual social maladjustment and contribute to its social reintegration. Initially, the centres performed more caring and educational functions, and their primary task was to support social educational actions undertaken by the probation officer.

In 1976, another ordinance of the Ministry of Justice enhanced the nature of attendance centres functioning. In addition to the current tasks related to social educational care, supervision over juveniles or supervision over the exercise of parental responsibility, the attendance centre also began to perform prevention functions.

In 2000, after the amendment to the Act on Juvenile Delinquency Proceedings, not only the name of the institution was changed to "attendance centre". As well, the procedures and principles of establishment and liquidation of centres, supervision over them, their organization and scope of activity were established ${ }^{15}$. From that moment on, attendances centres became institutions of prevention and social rehabilitation. The programs and services, which according to prof. Krystyna Marzec-Holka: "[...] can be considered as one of the forms improving the current upbringing system, because they are undertaking interactions towards the planned organization of the social environment of juveniles, their families, peer groups, outside of school environment and place of residence"16. Despite almost 50 years of successful functioning and incorporating inclusion of services that involve broader social systems within the local community in which the juvenile lives, attendance centres have still not received adequate funding and support. Notwithstanding the numerous benefits that attendance centres have provided, such as work in an open social environment, the possibility of group and

13 Ustawa z 26 października 1982 r. o postępowaniu w sprawach nieletnich (Dz.U. 2010, nr 33, poz. 178 ze zm.).

${ }_{14}$ Paweł Kozłowski, Krzysztof Stasiak, Ośrodek kuratorski. Ujęcie prawne, organizacyjne i metodyczne (Warszawa: Rzecznik Praw Dziecka, 2018), 11.

15 Zarządzenie Ministra Sprawiedliwości z dnia 6 lutego 1976 roku - §1, ust. 2.

16 Kozłowski, Stasiak, Ośrodek..., 11-13. 
system work, use of social capital and community resources, and lower operating costs compared to custodial institutions have not resulted in adequate funding resources for attendance centres ${ }^{17}$.

Prof. Wiesław Ambrozik puts attendance centres at the head of other community-based programs that are responsible for youth at risk of demoralization and social maladjustment ${ }^{18}$. According to the Prof. Ambrozik, decentralization as well as empowerment of social rehabilitation programs at the local level provide the necessary framework for integrating appropriate social services capable of resolving problems associated with existing deficits in prosocial educational programs and services. The key condition he considers to be crucial is the "thorough cleansing and re-organization" of maladjustment in the community and monitoring of educational and ongoing monitoring and of the forces of social negligence ${ }^{19}$. With regard to attendance centres, it is worth noting six statutory functions that they are expected to fulfil, they are the following: social rehabilitation; socialization; caring; prevention; therapeutic and diagnostic functions ${ }^{20}$; and reconstruct values using evidence-based practices.

First of functions carried out by attendance centers is the social rehabilitative function. The primary aspect of this function is socialization, defined as participation of individual in prosocial social groups and acquiring social roles by assimilating of certain commonly accepted obligations, values and norms ${ }^{21}$. The ultimate goal of this process is improvement of youth functioning in expected and socially accepted everyday life and social roles ${ }^{22}$. As mentioned earlier, the process is one of increasing the participation of at-risk and delinquent youth in social life. Therefore, it cannot take place outside of community where the youth live. To fully support youth in this process, the institutions must cooperate with key actors and groups in a local community. By doing so, youth can benefit from local support for leisure activities, prosocial cultural values, sports and ultimately developing their own potential withing the parameters of socially acceptable behaviours. The rehabilitative function can be carried out through group work, which is particularly important at the earlier stages of social rehabilitation. Tutors can model behaviour and respond to group dynamics appropriately. In fact, role modelling is a key component of evidence-based practices ${ }^{23}$.

17 Krystyna Marzec-Holka, "Działalność kuratorskich ośrodków pracy z młodzieżą", Studia Pedagogiczne 2 (1976), 90.

18 Kozłowski, Stasiak, Ośrodek..., 11-15.

19 Ambrozik, Społeczność..., 168.

20 Ibidem, 167.

${ }^{21}$ Kozłowski, Stasiak, Ośrodek..., 11-15.

22 Wiesław Ambrozik, W stronę uspołecznienia systemu oddziaływań (Kraków: Oficyna Wydawnicza "Impuls", 2016), 158.

${ }^{23}$ Cheryl B. Stetler, Judith A. Ritchie, Jo Rycroft-Malone, Martin P. Charns, "Leadership for Evidence-Based Practice: Strategic and Functional Behaviours for Institutionalizing EBP”, Worldviews on Evidence-Based Nursing 11 (4) (2014), August, 219-226. 
The second measure used in local community is based on individual participation in variety of activities, which fosters the social competencies and a sense of responsibility by maladjusted youth ${ }^{24}$. Anna Fidelus underlines the need for including the local community in the process of social rehabilitation and names the process as "inclusive social rehabilitation"25. The essence of this process is ongoing activities (according to youth abilities and potentials) which are oriented towards proactive participation of youth in the full panoply of behaviours that constitute prosocial everyday life. This is a never ending process, which relies on stimuli that comes from the crucial role of community play. According to Fidelus, local communities should create and develop a "culture of inclusion" by building a supportive social networks based on the foundations of diversity and feelings of inclusive belonging. Probation officers, street workers, and other service providers who are engaged directly in working with youth must play the main role in building a supportive community of inclusion. Those people described as "new approach ambassadors" would create a positive social image of maladjusted at-risk youth and juvenile delinquents in the local community ${ }^{26}$.

As indicated by research findings generated by the Krajowa Rada Kuratorów National Council of Probation Officers (further in the text: KRK), attendance centres are one of the most effective measures against anti-social behaviours and feelings of hopelessness; much more than other formal sanctioning measures. The majority of the 1600 juvenile court orders that stipulate participation in an attendance centre are based on truancy. As a result of supportive probation officers and tutors working in attendance centres, over 1200 of these youth returned to school again, and only one-eight of the original number of these juvenile delinquents committed new offences that required court involvement. The research on six attendance centres in Warsaw and two in the towns of Bielsk Podlaski and Hajnówka revealed that attendance centres effective in social rehabilitation as a result of increased school attendance for heretofore truant youth.

Researchers for the KRK interviewed 100 attendees and analyzed their documents and records. They did this to better understand the effectiveness of social rehabilitative work in attendance centres. The researchers quantified the degree of social maladjustment before referral and during the time spent in an attendance centre. Of the 100 attendees 86 complied with legal standards, and only 14 committed new offences. These results provide support for the belief that participating in attendance centres improves educational performance and prevented chronic school absenteeism. Of particular interest was the finding that almost every runway youth stopped fleeing from their homes ${ }^{27}$.

24 Marek Konopczyński, Pedagogika resocjalizacyjna. W stronę działań kreujących (Kraków: Oficyna Wydawnicza "Impuls", 2014), 9.

25 Anna Fidelus, "W stronę resocjalizacji inkluzyjnej”, Probacja 2 (2011), 70-86.

26 Kozłowski, Stasiak, Ośrodek..., 68.

27 Fidelus, "W stronę resocjalizacji...", 72. 
Another of attendance centres major functions is the socialization one, closely tied with a permanent process of helping maladjusted youth to re-think the consequences of their anti-social thoughts and behaviours. Attendance centres become a crucial element for probation officers in fulfilling their resocialization and social rehabilitation tasks. The current case management model does not support these kinds of activities by probation officers ${ }^{28}$. In addition to the rehabilitative work with attendees, the probation centres provide services that support the parents and guardians in fostering prosocial thinking and behaviours. This is done through workshops, individual counselling, setting common goals, teaching appropriate parenting methods, and including the parents in the process of social rehabilitation ${ }^{29}$. Parents or guardians form an alliance with probation officers, and continue in-home social rehabilitation services that began in attendance centres. This is likely the reason why among top ten evidence-based programs identified by Washington State Institute of Public Policy, five are programs that include parents as a partners in social rehabilitation of youth (two of recommended programs are specifically designed for use in probation - Functional Family Therapy, Functional Family Probation and Parole) $)^{30}$.

Those working and volunteering in attendance centres also fulfil the mentoring goals that fall within the purview of the caring function of the attendance centres. One study conducted by Oxford University showed that communal eating promotes social bonding, reinforces well-being and overall satisfaction with life. Eating socially at the dinner table, preparing food together, and the concomitant rituals that are involved with these informal activities provides much-needed structure to the daily lives of youth ${ }^{31}$. For example, the planning of a shared meals is a purposeful task. Not only does it teach the youth responsibility and obligations to others, but also fills the gaps in organizes their free time. A surplus of leisure along with boredom results in the participation in risky behaviours ${ }^{32}$. In fact, the research conducted by the KRK also affirms the aforementioned link between structuring time and reduction in anti-social behaviour. Most of attendance centre orders made by juvenile court were on basis of truancy (862), battery (299), alcohol and substances abuse (203), running away (74), others $(462)^{33}$. Moreover,

28 Andrzej Bałandynowicz, "Skuteczność i efektywność pedagogiczna ośrodków kuratorskich w Polsce", Policja 1 (2012), 14.

29 Maciej Muskała, Justyna Kusztal, "Kurator sądowy wobec nowych zadań i zmian w systemie resocjalizacji”, Studia Paedagogica Ignatiana (2018), 30.

30 Kozłowski, Stasiak, Ośrodek..., 70.

31 Children and Family Justice Center, Parents as Partners: Family Connection and Youth Incarceration, 2018, 6, https:/www.law.northwestern.edu/legalclinic/cfjc/documents/communitysafetyfeb.pdf (access:12.02.2020).

32 Lisa Wegner, "Through the Lens of Peer: Understanding Leisure Boredom and Risk Behaviour in Adolescence", South African Journal of Occupational Therapy 41 (1) (2011), 18-24.

${ }^{33}$ Robin Dunbar, "Breaking Bread: The Functions of Social Eating", Adaptive Human Behavior and Psychology, 3 (2017), 198-211. 
the program participants in the attendance centres can for the first time in their lives order food in a restaurant, or prepare a meal by themselves. Supplementary feeding takes many forms, from preparing sandwiches, cooking together, catering, to going out to restaurants. The only limiting factor is the budget. Funding for daily supplementary feeding vacillates between 4 and 7 PLN per attendee $(1-2 \text { USD })^{34}$.

Through the partnerships with therapists, psychotherapists, addiction therapists, art therapists, attendance centres pursue a multitude of therapeutic functions. Partnership between non-government organizations and attendance centres is a crucial factor in raising additional funds and having an access to specialized assistance. Cooperation gives the opportunity to involve social workers, psychologists, speech therapists, tutors, music therapists, sport therapists and prevention specialists otherwise financially non-achievable.

Attendance centres also do accomplish a prevention function. The prevention goals are achieved on two levels - primary prevention (oriented towards individuals in the high risk of maladjustment and dysfunction) and on the level of secondary prevention (comprising of groups already having symptoms of dysfunction and behavioural problems). The first level is carried through creating a safe environment for youth, which would be an alternative for unsupervised activities with antisocial peer groups. On the secondary level, attendance centre programs focus on treating, delaying and preventing the progress of continued social maladjustment. On both levels attendance centres must cooperate with local institutions to create opportunities for the attendees to participate in professionally customized programs $s^{35}$. An example of such partnership is "Odlot" ("Take-off") program, developed by specialists in Institute of Psychiatry and Neurology in Warsaw. This evidence-based program includes a complex diagnosis of local community problems, developing and pushing for local preventive initiatives. Evaluations have shown that the program, not only improved cooperation between local institutions within participating communities by developing a social network, but also increased the rate of children not taking any psychoactive substances by seven points The rate of children not taking psychoactive substances in control group decreased by 11 points ${ }^{36}$.

Evidence-based practices in Poland can also be found in the longstanding work of the Integrated Intervention Institute (Instytut Profilaktyki Zintegrowanej

34 Others like: preventive measure against demoralization, smoking, stealing, criminal offences, sexual offences, property damage, frauds, agressive behavior, pocketing, extortions, breaking ins, vulgar and arrogant behavior at school, possession of drugs, menacing, postponement of placing in Youth Fostering Centre

See Łukasz Kwadrans, "Diagnoza aktualnej sytuacji i propozycje rozwoju ośrodków kuratorskich”, Probacja 3 (2012), 115.

${ }_{35}$ Kozłowski, Stasiak, Ośrodek..., 71.

36 Ibidem. 
[further in the text: IPZIN]), which resulted in creating recommendations entitled Seven Leverages of Effective Intervention. The inference of the word leverage comes from an effect that could be obtained with relatively minimal resources ${ }^{37}$. In their daily activities attendance centres, perhaps knowingly or not, use evidence-based practices found in the Seven Leverages.

Identifying the potential strengths of program participants, accumulating and disseminating positive data about the local community is the first of seven recommendations made by IPZIN. Correct diagnosis is, according to aforementioned research, the cornerstone for searching for creative solutions residing within community. Local authorities should encourage research, projects, programs and strategies which highlight youth successes, positive attitudes of parents, and teachers and mentors. Such actions would result in reinforcing and raising support in the local environment. This in turn would lead to a change of the community mindset about solutions for problems of maladjusted youth ${ }^{38}$. Example of such an imitative is a short documentary Na imię mam... ${ }^{39}$ (My Name Is...), created by juvenile participating in socio-vocational activization project SZANSA (CHANCE), customized for attendance centres. Other examples of such initiatives are Zielone glowy ${ }^{40}$ (Green Heads), portraying the co operational work of attendees from 3. Attendance Centre and the Children's Art Centre in Poznań.

The second strategy that can be leveraged underlines the importance of complex preventive actions oriented towards current problems and potentially risky behaviours. Risky behaviours are often interconnected and work in a feedback loop. For example, one risky behaviour may very well have the potential to increase the occurrence of other risky behaviours. Because of this interconnectedness, there is a need for partnership among educational, preventive, childcare-mentoring and social rehabilitation institutions. Such cooperation across all of these entities could facilitate programs and services that address the etiology of risky behaviours. Attendance centres implement this principle, by offering at-risk youth a broad, but specialized array of programs and services. Local strategies should include multidimensional diagnosis of strengths and weaknesses of resident population $s^{41}$. The strategies should strengthen the cooperation between local institutions by clearly defining the forms that joint actions will take. Of note is the fact, that attendance centres have a legal duty to cooperate with public and social institutions, local authorities and other trustworthy people ${ }^{42}$.

37 Jacek Moskalewicz, Janusz Sierosławski, Grażyna Świątkiewicz, "Program zapobiegania narkomanii w Polsce 'Odlot”', Alkoholizm i Narkomania 2 (27) (1997), 226.

38 Szymon Grzelak, Vademecum skutecznej profilaktyki problemów młodzieży (Warszawa: ORE, 2015), 156.

39 Ibidem, 157.

40 https://www.youtube.com/watch?v=XmEBlKSYJnI\&feature=emb_title (access: 2.01.2020).

${ }^{41} \mathrm{https} / /$ www.youtube.com/watch?v=Bz_WszYhHew (access: 2.01.2020).

42 Grzelak, Vademecum..., 156. 
The third activity that affords leverage directs attendance centres to take into account the resources of local community and its own protective factors as foundation of work ${ }^{43}$. The protective factors in local environment are potentially family, school, religious organizations, non-governmental organizations (NGOs), youth organizations and governmental entities. They all have the potential to create and sustain significant social capital which would be invaluable to the mitigation of individual and social factors associated with at-risk and delinquent populations.. Attendance centres currently endorse the principle of grounding their work in local communities. A proud example of such activity is the work of 3. Attendance Centre in Poznan, which through the partnership with the local community took part in drama festival, "Wychowanie przez Teatr" ("Educating Through Theatre"), and in International Young Viewer Movie Festival "Ale Kino!". This centre also organized an exhibition of one of attendee's art work in local art gallery. Through these and many other actions of attendance centres, program participants are being proactively included into their local community, and demonstrating their abilities and potential. Most importantly, they have the opportunity to create a positive social image and put into action their dreams and goals. The latter two, are the fourth level of Effective Prevention. As the IPZIN study shows, the more important the goal is to youth, the more they can endure to reach it. Probation officers working in attendance centres are architects of providing choices for the youth. They develop meaningful and socially acceptable ways of fulfilling the needs of at-risk youth and juvenile delinquents. Through appropriate support services from probation officers, the attendees withdraw from seeking instant gratification in alcohol, drugs, spontaneous sex, or escaping into the virtual world.

The fifth recommendation concludes that re-socialization and prevention should be a local and national priority. Quoting Szymon Grzelak "It is the duty of local and national authorities to create the best possible foundations for families to perform the upbringing and preventive tasks, help institutions which support families and assist the upbringing process in those fields and topics in which professional, specialistic knowledge and other resources are limited"44. As mentioned earlier in this article, attendance centres support the family both in preventive function and in bringing program participants through the workshops with parents or legal guardians.

Sixth of the Seven principles of Effective Intervention recommends a need to search for the greatest effects and the most efficient expenditure of resources. The healthcare system has tool known as CEA (Cost Effectiveness Analysis) that analyzes efficiency and effectiveness of programs and services. This tool compares

43 Rozporządzenie Ministra Sprawiedliwości z dnia 5 października 2001 r. w sprawie ośrodków kuratorskich (Dz.U. 2001, nr 120, poz. 1294).

44 Grzelak, Vademecum..., 159. 
costs and benefits of a variety of healthcare protocols and programs. As the data mentioned earlier in the text shows, the attendance centres are both the cheapest and most effective legal measure for at-risk youth and juvenile delinquents in Poland. In order to create a holistic and effective strategy it is crucial for attendance centres to cooperate with other institutions in local environment that also provide evidence-based prevention programs ${ }^{45}$. Program "Śnieżna Kula", based on American "Operation Snowball" is shining example of such teamwork. Implemented by Preventive-Developmental Centre for Youth and Children in Łódź, the program created a supportive social network for both youth and adults in the local community. This program created and encouraged alternatives for alcohol and drug abuse and other destructive behaviours, by allowing youth and adults to take care of each other in a healthy resilient local community ${ }^{46}$.

The last recommendation calls attention to the importance of engaging people who are passionate about youth in prevention work. The attitudes of probation officers and other counsellors, coupled with their skills and routine treatment of attendees have great impact on the effectiveness of programs. Apart from the local cooperation aspects of programs and services, the very process of establishing appropriate rapport between service providers and program participants is crucial for a successful work ${ }^{47}$. A successful working alliance ${ }^{48}$ between probation officer and attendee has greater impact on positive effects of social rehabilitation than the program itself. Probation officers working in attendance centres can develop an autotelic ${ }^{49}$ (possessing internal purpose) bond between youth and service providers they have an appropriate environment to do so.

Cooperation in attendance centres is built upon trustworthy, passionate people, as well as strengthening local community networks, which in turn creates a mutually motivating team that can endure many hardships, prevent burnout, but most importantly creates a common goals ${ }^{50}$. The work of Attendance Centre in Białystok is an example of the mentioned Principles of Effective Prevention. In the Białystok, effectiveness of social rehabilitation is measured by creating new identity parameters throughout various ways of developing the potential of the program participant. Including youth in many local initiatives and creating new ones are the foundation of any activities in the Białystok program. Environmental factors iare crucial in creating the new identity parameters in juvenile. This factor

45 Ibidem, 170.

46 Ibidem, 195.

47 Grażyna Świątkiewicz, Profilaktyka w środowisku lokalnym (Warszawa: KBPN, 2002), 152.

48 Patrick Kennealy, Jennifer Skeem, Sarah Manchak, Jennifer Eno Louden, "Firm, Fair and Caring Officer-Offender Relationships Protect Against Supervision Failure", Law and Human Behavior (2012).

49 Adam Horvath, Leslie Greenberg, "Development and Validation of the Working Alliance Inventory”, Journal of Counseling Psychology 36 (2) (1989), 223-233.

50 Czesław Czapów, Stanisław Jedlewski, Pedagogika resocjalizacyjna (Warszawa: Państwowe Wydawnictwo Naukowe, 1971), 308-346. 
is the social context of the aspirations of attendees, in which social spectators (i.e., the local community) have the possibility of giving the positive feedback. Every activity of the attendees in Białystok program is finalized by presenting the effects of the juvenile work to social spectators through engaging the attendees in sports tournaments, creating art exhibitions coupled with a seminar, musical, artistically and drama performances ${ }^{51}$.

The last of the functions of attendance centres is the diagnostic function. It's the last function of the institution mentioned in this paper, but not the least important. This is because attendance centres have a significantly critical diagnostic potential. Probation officers working in those institutions have vast knowledge about the local community, its problems and hidden potentials. Juveniles directed by a court order to become an participant of attendance centre bears the responsibility to engage in his/her own change. S/he needs to make the effort to participate and adapt to the program. By engaging in this conscious effort, the program participant takes independent steps towards change. Regular attendance of juvenile in the program often results in the court reconsidering its position regarding adjudication and ordering the lighter disposition. Probation officers working in attendance centres can immediately start working with a juvenile in ways that are in the child's best interest. Early court intervention vis a vis an attendance centre order, allows for a in-depth observation and assessment of functioning of the juvenile in the peer group ${ }^{52}$.

Apart from individual diagnosis of every attendee, probation officers working in attendance centres also diagnose the functioning of attendee's family, peer group, school and local environment. The latter can yield beneficial outcomes both for juvenile, and for local authorities by reducing the institutionalization costs. This idea is an evidence-based practice, which was already put into life in Community Based Diagnostic Program for Juvenile Offenders in Washington. This program foundation was based on the need for cooperation between specialists that function in the environment that is closest to the juvenile participating in the attendance centre. Each individual diagnostic work-up depends on need of the program participant. The diagnostic process generally includes psychological testing, education evaluation, ministerial study, detention evaluation, family dynamics evaluation, psychiatric, medical and additional evaluations.

The community-based diagnostic program has had a significant impact on reducing commitment to state institutions from $40-50$ per year to $15-11$ per year, saving institutional costs and reducing the recidivism rate among juveniles. The comparison between what is actually available and what is actually needed

51 Grzelak, Vademecum..., 214.

52 Karol Konaszewski, "Kształtowanie tożsamości młodzieży nieprzystosowanej w środowisku otwartym (na przykładzie Ośrodka Kuratorskiego w Białymstoku)”. In: Środowiskowy wymiar niedostosowania, eds. Krzysztof Sawicki, Karol Konaszewski (Białystok: Agencja Wydawnicza Ekopress, 2014), 74 . 
regarding services highlights the lack of necessary resources that are needed to implement and expand new specialized programs such as intensive treatment foster homes. In addition, courts began to use the local community resources in their orders, which enabled closer working relationship between treatment institutions and the juvenile court ${ }^{53}$. Undoubtedly attendance centres follow the principles of social rehabilitation in local community. With this philosophy in mind, they reach out to the root causes of antisocial, delinquent, and criminal behaviour among at-risk youth and juvenile delinquents delinquent.

Criminal behaviour among youth is shaped by a faulty socialization processes. Reconstruction and rehabilitation should take place in the healthy, resilient local community environments as opposed to in isolation. At-risk youth and juvenile delinquents must proactively be included in the process of social rehabilitation in order to produce. Meaningful engagement of program participants in attendance centres foster positive outcomes through empowering the potential and resiliency of the program participants. Attendance centres do not separate the youth from their environment, especially family, instead they provide the opportunity for in-depth observation and intervention in the local community. The functions which attendance centres fulfil are consistent with premises of evidence-based practices. Unfortunately, public opinion and many of those who are elected to represent them are misguided in their beliefs about the efficacy of deterrence-based penalties and their own public safety. The research is clear. Providing social and individual rehabilitation services offer the greatest promise for increases in public safety. If harsh punishments are needed in order to assuage a sense of justice for crime victim, they should be understood as possible solutions for a sense of justice for some, but not a pathway to increased public safety in the short or long-term.

\section{Idea pracy z nieletnim w społeczności lokalnej - o działalności ośrodków kuratorskich na podstawie Evidence-Based Practice}

Streszczenie: W niniejszym artykule na przykładzie ośrodków kuratorskich pokazano koncepcję pracy z nieletnimi w społeczności lokalnej, która skupia się na funkcji uspołeczniania jednostki oraz zakłada, iż niedostosowanie społeczne i przestępczość nieletnich mają swoje źródła w wadliwym funkcjonowaniu środowiska społecznego. Idea ta stosowana w praktyce wykazuje wysoką skuteczność i przyczynia się nie tylko do spadku przestępczości, ale również pełni funkcje profilaktyczne, angażując społeczności lokalne w swoje działania.

Słowa kluczowe: praktyki oparte na dowodach, ośrodek kuratorski, resocjalizacja nieletnich

53 Kozłowski, Stasiak, Ośrodek..., 73. 


\section{References}

Ambrozik, Wiesław. "Społeczność lokalna jako płaszczyzna funkcjonowania systemu profilaktyczno-resocjalizacyjnego”. Resocjalizacja Polska 1 (2010), 157-173.

Ambrozik, Wiesław. W stronę uspołecznienia systemu oddziaływań. Kraków: Oficyna Wydawnicza "Impuls", 2016.

Bałandynowicz, Andrzej. "Skuteczność i efektywność pedagogiczna ośrodków kuratorskich w Polsce”. Policja 1 (2012).

Children and Family Justice Center. Parents as Partners: Family Connection and Youth Incarceration, 2018, 6, https://www.law.northwestern.edu/legalclinic/cfic/documents/communitysafetyfeb.pdf (access:12.02.2020).

Cox, Gary, Carmichael, Stephen, Dightman, Cameron. "An Evaluation of a Community Based Diagnostic Program for Juvenile Offenders". Juvenile and Family Court Journal 28, (3) (2009).

Czapów, Czesław, Jedlewski, Stanisław. Pedagogika resocjalizacyjna. Warszawa: Państwowe Wydawnictwo Naukowe, 1971.

Dunbar, Robin. "Breaking Bread: The Functions of Social Eating". Adaptive Human Behavior and Psychology 3 (2017), 198-211.

Efektywność resocjalizacji nieletnich $w$ warunkach wolnościowych, eds. Zdzisław Bartkowicz, Anna Wojnarska, Andrzej Węgliński. Lublin: Wydawnictwo UMCS, 2013.

Europejskie statystyki przestępczości, https://wp.unil.ch/europeansourcebook/ (access: 3.12.2019).

Fidelus, Anna. "W stronę resocjalizacji inkluzyjnej”. Probacja 2 (2011), 70-86.

Grzelak, Szymon. Vademecum skutecznej profilaktyki problemów młodzieży. Warszawa: ORE, 2015.

Horvath, Adam, Greenberg, Leslie. "Development and Validation of the Working Alliance Inventory". Journal of Counseling Psychology 36 (2) (1989), 223-233.

Kennealy, Patrick, Skeem, Jennifer, Manchak, Sarah, Louden Eno, Jennifer. "Firm, Fair, and Caring Officer-Offender Relationships Protect Against Supervision Failure". Law and Human Behavior (2012).

Konaszewski, Karol. "Kształtowanie tożsamości młodzieży nieprzystosowanej w środowisku otwartym (na przykładzie Ośrodka Kuratorskiego w Białymstoku)”. In: Środowiskowy wymiar niedostosowania, eds. Krzysztof Sawicki, Karol Konaszewski. Białystok: Agencja Wydawnicza Ekopress, 2014.

Konopczyński, Marek. Pedagogika resocjalizacyjna. W stronę działań kreujących. Kraków: Oficyna Wydawnicza "Impuls", 2014.

Kowalski, Stanisław. "Środowisko lokalne w wychowawczym funkcjonowaniu społeczeństwa”. Rocznik Pedagogiczny 9 (1984).

Kozłowski, Paweł, Stasiak, Krzysztof. Ośrodek kuratorski. Ujęcie prawne, organizacyjne i metodyczne. Warszawa: Rzecznik Praw Dziecka, 2018.

Kwadrans, Łukasz. “Diagnoza aktualnej sytuacji i propozycje rozwoju ośrodków kuratorskich”. Probacja 3 (2012), 115.

Marzec-Holka, Krystyna. “Działalność kuratorskich ośrodków pracy z młodzieżą”. Studia Pedagogiczne 3 (1977), 90-105.

Moskalewicz, Jacek, Sierosławski, Janusz, Świątkiewicz, Grażyna. “Program zapobiegania narkomanii w Polsce 'Odlot”'. Alkoholizm i Narkomania 2 (27) (1997), 197-230.

Muskała, Maciej, Kusztal, Justyna. "Kurator sądowy wobec nowych zadań i zmian w systemie resocjalizacji”. Studia Paedagogica Ignatiana (2018).

Muskała, Maciej. Odstapienie od przestępczości w teorii i praktyce resocjalizacyjnej. Poznań: Wydawnictwo Naukowe UAM, 2016. 
Na imię mam..., YouTube, https://www.youtube.com/watch?v=XmEBlKSYJnI\&feature=emb_title (access: 2.01.2020).

Ross, Andy, Duckworth, Kathryn, Smith, David, Wyness, Gill, Schoon, Ingrid. Prevention and Reduction: A Review of Strategies for Intervening Early to Prevent or Reduce Youth Crime and Anti-social Behaviour. Department for Education (DFE), 2011. https://www.ifs.org.uk/publications/5594 (access: 15.02.2020).

Rozporządzenie Ministra Sprawiedliwości z dnia 5 października 2001 r. w sprawie ośrodków kuratorskich (Dz.U. 2001, nr 120, poz. 1294).

StatystykiBiuraPrewencjiKomendyGłównejPolicji, https://wp.unil.ch/europeansourcebook/ (access: 3.12.2019).

Stetler, Cheryl B., Ritchie, Judith A., Rycroft-Malone, Jo, Charns, Martin P. "Leadership for Evidence-Based Practice: Strategic and Functional Behaviours for Institutionalizing EBP”.Worldviews on Evidence-Based Nursing 11 (4) (2014), August, 219-226.

Świątkiewicz, Grażyna. Profilaktyka w środowisku lokalnym. Warszawa: KBPN, 2002.

Ustawa z 26 października 1982 r. o postępowaniu w sprawach nieletnich (Dz.U. 2010, nr 33, poz. 178 ze zm.).

Wegner, Lisa, "Through the Lens of Peer: Understanding Leisure Boredom and Risk Behaviour in Adolescence". South African Journal of Occupational Therapy 41 (1) (2011), 18-24.

Zarządzenie Ministra Sprawiedliwości z dnia 6 lutego 1976 roku $-\$ 1$, ust. 2.

Zielone głowy, YouTube, https://www.youtube.com/watch?v=Bz_WszYhHew (access: 2.01.2020). 